\title{
O mundo sem luz: ensinando física a alunos com deficiência visual
}

\author{
Felipe Correa Silvano ${ }^{1}$, Wellington Barbosa de Paula ${ }^{2}$, Mironaldo Batista Mota Filho ${ }^{3}$, Ana Rita Pereira 4 . \\ 1, 2, 3 Universidade Federal de Goiás (UFG) - Catalão \\ ${ }^{4}$ Escola Estadual Madre Maria Blandina - MG
}

Palavras-Chave: Deficiência Visual; Maquetes táteis-visuais; Ensino de Física.

\section{Introdução}

As políticas educacionais brasileiras determinam a inclusão social de alunos com necessidades educacionais especiais (NEE) em turmas regulares de ensino. Mas para que a Educação Especial, ou Educação Inclusiva, se torne realidade é necessário adaptações do sistema educacional, seja pela adoção de recursos específicos, novos métodos, novas estratégias de ensino e o uso de materiais alternativos, seja pela adaptação dos currículos e dos docentes para a realidade dos alunos NEE, de forma a promover boa educação para todos os alunos.

É crescente a presença de alunos NEE nas salas de aula, mas como essa inclusão exige soluções que podem ser bastantes trabalhosas devido à diversidade de necessidades especiais (RODRIGUES, 2003), poucos avanços têm sido observados no processo educacional. Muitas vezes o educador só considera a inclusão ao se deparar com um aluno NEE na sua sala de aula, e ai se depara com carência de métodos, estratégias de ensino e alternativas que garanta a aprendizagem efetiva desse aluno, sendo que existem alunos NEE que chegam a ser ignorados por docentes durante as aulas.

Esse trabalho estuda a problemática do Ensino de Física, na perspectiva da Educação Inclusiva, em particular analisando o Ensino de Física para alunos com deficiência visual (aluno DV). Considerando que as metodologias e estratégias de Ensino de Física exploram amplamente a percepção e a representação visual, aprender Física se torna um complicador e um desafio para o aluno DV. E para garantir a participação e o aprendizado do aluno DV, o Ensino de Física precisa se adequar às necessidades desse aluno, possibilitando sua participação ativa nas aulas. $E$ isso provoca discussões inerentes à utilização das múltiplas percepções sensoriais para que o escolar assimile de forma heterogênea os diversos saberes científicos. Nesse sentido tem sido trabalhado a estruturação de um laboratório didático/instrumental de apoio aos docentes de Física, "o mundo sem luz", com o objetivo de dar suporte as investigações e que atenda às necessidades educacionais de todos os alunos, videntes e não videntes, nas aulas de Física.

\section{Metodologia e material}

Um aluno DV pode entender os fenômenos da natureza de forma diferente, mas sua capacidade de aprender não é diferente de alunos videntes. De acordo com Azevedo (AZEVEDO, 2012) para incluí-los o docente pode utilizar ferramentas que atendam às suas especificidades, mudando o seu referencial observacional para o tátil, auditivo ou sinestésico. Assim uma estratégia é criar ou adaptar materiais que represente os fenômenos físicos abordados na aula utilizando, por exemplo, material em alto relevo, escrita em Braille, quadros magnéticos e maquetes táteis-visuais, que possibilite ao aluno DV a compreensão das explicações do assunto estudado (AZEVEDO, 2012; CAMARGO, 2007).

Buscando a inclusão do aluno DV no âmbito do ensino de Física, o projeto "mundo sem Luz" tem pesquisado, elaborado e confeccionado maquetes táteis-visuais que exploram e valoriza todos os aspectos sensoriais, como o aspecto tátil, visual e expositivo, de forma a auxiliar as necessidades educacionais dos alunos videntes e não videntes nas aulas de Física, somando no campo pedagógico, pois inclui todos os alunos, sem exceção. $E$ também têm sido pesquisadas formas de utilizar tais maquetes nas aulas de Física, inclusive realizando aulas com os alunos videntes vendados, o que possibilita aos mesmos refletir sobre a realidade do colega DV. Com base na experiência adquirida com o projeto, são apresentados resultados e discussões sobre o tema. 


\section{Resultados e discussão}

O projeto "mundo sem luz" é uma continuidade das atividades iniciadas numa dissertação no Programa de Mestrado Nacional Profissional em Ensino de Física (MNPEF) em 2015 (MOTA FILHO, 2015), que trabalhou algumas possibilidades de ensinar Física a um aluno cego, com destaque para maquetes construídas com materiais em relevo ou experimentos demonstrativos dos fenômenos eletromagnéticos. De acordo com esse aluno: "Posso dizer que a utilização desses materiais táteis foi imprescindível para que eu efetivamente aprendesse, pois como já mencionado, os conteúdos exigiam mais do que nunca, análise de imagens" (Fala do aluno DV), o que mostra que as maquetes auxiliam na construção dos modelos mentais e no entendimento dos conceitos físicos. E usar o Braille nas maquetes garante ao aluno DV mais autonomia e desenvoltura, além de possibilitar a ele fazer individualmente as próprias avaliações.

Atualmente o laboratório "Mundo sem Luz" tem um acervo que visa o estudo dos diversos fenômenos físicos, a exemplo da representação dos movimentos, Via Láctea, Terra, difração, interferência, onda eletromagnética entre outros. E tem um aluno do MNPEF trabalhando especificamente os conteúdos de óptica. Explorar maquetes em relevo ou materiais concretos fornece mais informações e subsídios para a construção dos conceitos físicos de todos os alunos. Segundo Camargo (CAMARGO, 2011) usar artefatos, que estimula as percepções auditivas, táteis e visuais, traz elementos enriquecedores às aulas, favorece o entendimento das explicações do professor e contribui para melhorar o aprendizado de todos os alunos, com ou sem deficiência.

\section{Conclusões}

No projeto "O mundo sem luz", experimentos têm sido elaborados e confeccionados para explicar variados fenômenos físicos. Essas maquetes têm sido utilizadas nas aulas de Física representando as figuras e esquemas visuais usados pelo docente, sendo usadas também por alunos videntes.

Outra atividade realizada é com as pessoas vendadas, vivenciando a experiência de usar outros sentidos, como o tato e a audição, para entender a Física. Percebe-se com essa atividade uma mudança de atitude dos alunos em relação à situação do colega DV. Muito mais que aprender física "no escuro", esta atividade contribui para que entendam as peculiaridades de cada indivíduo, com deficiência ou não. Essa é uma oportunidade de mostrar a inclusão como forma de garantir a valorização da diversidade humana, com todos aprendendo e convivendo juntos num mesmo espaço democrático, igualitário e justo.

\section{Agradecimentos}

Ao CNPQ, CAPES, FAPEG e UFG, pelo apoio financeiro e à Escola Estadual Madre Maria Blandina, Araguari, MG, onde foram desenvolvidas parte das atividades.

\section{Referências}

AZEVEDO, A. C. Utilizando material didático adaptado para deficientes visuais. Produto

Educacional. Programa de Mestrado Profissional em Ensino de Física - Instituto de Física - UFRJ Rio de Janeiro, 2012.

CAMARGO, E. P., Ensino de Física para alunos cegos ou com baixa visão. Física na Escola, v. 8, n. 1, 2007.

CAMARGO, E. P., Ensino de óptica para alunos cegos: possibilidades $-1^{1}$ a edição - Curitiba, PR: CRV, 2011.

MOTA FILHO, M. B. O ensino de eletromagnetismo para alunos com deficiência visual. 2015. 138 f. Dissertação (Mestrado em Ensino de Física). Universidade Federal de Goiás, Regional Catalão, Catalão, Go, 2015.

RODRIGUES, A. J., Contextos de Aprendizagem e Integração/Inclusão de Alunos com Necessidades Educativas Especiais. Em Ribeiro, M. L. S. e Baumel, R. C. R. (Org.., Educação

Especial: do querer ao fazer. São Paulo: Avercamp, 2003.

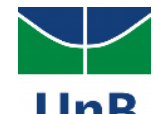

